WOJCIECH LIS

\title{
THE POLISH MINORITY IN ARMENIA
}

\section{INTRODUCTION}

The fate of the Polish nation is determined by its geopolitical location between Russia and Germany. The territory it inhabits is a kind of buffer zone between the East and West, and at the same time, the country is a keystone connecting cultures shaped under the influence of the Mediterranean and Turanian civilizations. Over the centuries, a high price had to be paid for this, including mass deportations and forced emigration. As a consequence, a huge number of Poles lived outside of Poland, whose descendants are found on all continents and in almost every country in the world. One of the areas where the Polish population settled was the Transcaucasus, including the historical lands of Armenia. ${ }^{1}$

It is a paradox that the history of Armenians in Poland and their merits won for the nation and Polish state are the subject of interest and academic research, while the history of Poles in Armenia is a very poorly developed and almost unknown issue. While information about the beginnings of Polish settlement in Armenia appears in the context of various studies on the Caucasus, knowledge about the lives of the Polish minority in Armenia in recent times is scarce, perhaps even non-existant. It is, therefore, necessary to bring this issue out of oblivion to show the intricate fate of the Polish nation and to remind us that also in these places far away from the homeland, Poles have settled long ago on the border between the Latin and Arab civilizations, and their descendants live there till present, admitting to their Polish origin.

Dr. Hab. WoJCiech Lis, CUL Professor - Faculty of Law, Canon Law and Administration, John Paul II Catholic University of Lublin; e-mail: wlis@kul.lublin.pl

${ }^{1}$ Armenia's proper territory covers not only the present-day Republic of Armenia (only $29,743 \mathrm{~km}^{2}$ ), but also the areas of today's eastern Turkey, the Armenian Highlands, to the upper Euphrates and eastern extremities of the Taurus mountains, northern Mesopotamia between lakes Urmia and Van, and western Azerbaijan, or more precisely the part located in today's Iran. 


\section{THE HISTORY OF POLISH SETTLEMENT IN ARMENIA}

The history of Polish settlement in Armenia basically begins after the fall of the Polish-Lithuanian Commonwealth. As a result of subsequent partitions imposed by Russia, Prussia and Austria initiated in 1772, Poland was eradicated from the map of Europe for 123 years. During the high point of the Polish-Lithuanian Commonwealth, the emigration of Poles to Armenia, enslaved by Turkey, Persia, and later Tsarist Russia, had no political, socio-economic or religious foundation. Only after its fall, their dramatic personal fates caused Poles to find themselves in the Caucasus, including Armenian territories. ${ }^{2}$ Until the end of the $18^{\text {th }}$ century, Poles only sporadically settled in Armenian territories, and since the end of the $18^{\text {th }}$ century, Poles began to arrive in Armenia because they were forced to serve in the tsar's army. Among them were participants of the Bar Confederation, Kosciuszko Uprising, Napoleonic Wars, participants of the subsequent November and January national uprisings, and other national liberation movements. Their numbers in various historical periods were assessed to be from several to tens of thousands of people. ${ }^{3}$

Tsarist Russia, which during this period was intensively colonizing North and Central Asia and the Caucasus, needed soldiers. These men were mainly taken from conscripts recruited by force to the Russian army, including from lands seized in Poland and forced to fight for the imperial interests of the tsars. Poles basically fought on all the fronts where Tsarist Russia conducted military operations, including in the Caucasus. They were stationed in Caucasian garrisons, which included all major cities and settlements in Armenia. Without a doubt, Poles took part in the capture of Yerevan in 1821, for which its conqueror Ivan Paskiewicz, the same man who suppressed the November Uprising, received the title of count from the tsar and the nickname Erewan. ${ }^{4}$

What is interesting to note is that, due to the Armenians' favoring Russia, which freed them from the captivity of their irreconcilable enemy, Turkey, Poles as their "allies" gained universal respect. The Armenians' favor, gained during the

${ }^{2}$ A. Koseski, Przemówienie inaugurujace sympozjum naukowe „Polacy w Armenii na tle dziejów ormiańskich", [in:] E. WALEWANDER (red.), Polacy w Armenii [Speech Inaugurating the Academic Symposium "Poles in Armenia in the Background of Armenia's History", [in:] E. WaLEWANDER (ed.), Poles in Armenia], Lublin 2000, p. 18.

${ }^{3}$ G. Piwnicki, Losy Polaków - wojskowych, stużacych $w$ armii carskiej na terenie Armenii w XIX i na poczatku XX w. [in:] E. Walewander (red.), Polacy w Armenii [The Fate of Poles. Military, Serving in the Tsarist Army in Armenia in the $19^{\text {th }}$ and Early $20^{\text {th }}$ Centuries, [in:] E. WaLEwANDER (ed.), Poles in Armenia], p. 237.

${ }^{4}$ A. Koseski, Polacy w Armenii: problematyka kwerendy i główne kierunki badań [Poles in Armenia: Query Issues and Main Research Directions], „Dzieje Najnowsze” 2000, no. 1, p. 195. 
Caucasian wars, caused that Poles came to them from different parts of Russia. After the fall of the November Uprising, the Caucasus became a "hot Siberia". It is estimated that about 9,000 Poles were deported there in 1832-1834 and incorporated into the Caucasian corps. Some of them served in Russian garrisons, which were deployed in Armenia. Spies were also sent to the Caucasus from Szymon Konarski's conspiracy, who were participants in Józef Zaliwski's guerrilla group, including revolutionary anti-tsar youth student circles. ${ }^{5}$

In the second half of the nineteenth century, Poles came to the Caucasus in search of work and opportunities to achieve professional success and social advancement. Here they had much better conditions for starting a career in life than in the European part of Russia. These were not, however, huge crowds. It is estimated that around 5,000 Poles lived in Armenia at the turn of the $19^{\text {th }}$ and $20^{\text {th }}$ centuries. According to the census carried out in the Russian Empire in 1897, the number of Poles (more precisely, those who spoke Polish as their native language) living in the territory of then Armenia (East and West) was 4,628 people. The vast majority, about $95 \%$ of all those who claimed Polish was their native language, were men, which was associated with the fact of military service in the tsarist army. ${ }^{6}$ The emigration of Poles, permanent and temporary, voluntary and forced, continued until the outbreak of World War I.

Stanisław Thugutt in his work Polska i Polacy. Ilość i rozsiedlenie ludności polskiej [Poland and Poles. The Number and Settlement of the Polish Population] (Warsaw 1915) estimates that in 1911, there were 36,100 Poles living in the Caucasus. ${ }^{7}$ The number of Poles in the Caucasus increased significantly during World War I. The outbreak of World War I meant that huge numbers of Polish refugees, assessed in historiography not very precisely as ranging from 1 million to 1.5 million people, found themselves in Russia. Some of these refugees also reached Armenia. In Yerevan, one of the many branches of the Polish Society for Assistance to War Victims was created in the Caucasus. ${ }^{8}$ The repatriation of the Polish

5 A. Patek, Polacy $w$ Rosji $i$ w ZSRR, [in:] B. Szydlowska-Ceglowa (red.), Polonia $w$ Europie [Poles in Russia and the USSR, [in:] B. Szydlowska-Ceglowa (ed.), Polonia in Europe], Poznań 1992, p. 288.

${ }^{6}$ Pierwaja wsieobszczaja pierepis nasielenija Rossijskoj Imperii 1897 goda, vol. 71, Petersburg 1905, p. 185 et seq.; Razpredielenije nasielenija Zakawkazskogo Kraja po wierospowiedanijam i rodnomu jazyku po dannym pierepisii 1897 g., [in:] Kawkazskij Kalendar na 1907 god, Tyflis 1906 , p. 90 et seq.

${ }^{7}$ M. Zakrzewska-Dubasowa (ed.), Polacy w kulturze i życiu społecznym Zakaukazia do $1918 \mathrm{r}$. [Poles in the Culture and Social Life of the Caucasus Until 1918], Lublin 1990, p. 12.

${ }^{8}$ Cf. W. Najdus, Uchodźcy polscy w Rosji w latach 1917-1919 [Polish Refugees in Russia in the Years 1917-1919], “Kwartalnik Historyczny” 1957, no. 6, pp. 26-40. 
population from the Caucasus region, including Armenia, began almost immediately after the conclusion of a peace treaty in Brest, Lithuania on March 3, 1918, between Soviet Russia and the German Empire, Austro-Hungary and their allies, the Ottoman Empire and the Bulgarian Empire. It was joined by the Royal Polish Representation in the Caucasus with headquarters in Tiflis (today's Tbilisi), the Polish Regional Council in the Caucasus, and then Poland's State Representation in the Caucasus. ${ }^{9}$

It is extremely difficult to determine the number of Poles in the population in the USSR in the interwar years. Polish historiographic data shows that between November 1919 and the end of June 1924, 1,264,845 people returned to Poland, including about 469,000 Poles. According to the 1926 census, taking into account nationality and native language, 182,334 people of Polish origin remained on the territory of the USSR, including 6,324 in the Caucasus. It is estimated that only 105 Poles lived in Armenia at that time, with the largest number in Leninakan (Kumajri). ${ }^{10}$ It is impossible to say today just how many Poles were deported to Armenia after the USSR invaded Poland on September 17, 1939. In addition, the war years of 1939-1941 were a period of mass deportations, mainly of soldiers and their families, to Siberia and Kazakhstan. Some of the Poles sent there managed to get into Armenia, influenced by, among others, a milder climate.

In addition, Armenia had a significant number of Poles who were evacuated from Western Ukraine during World War II. It is estimated that at the end of World War II, there were about 400 Poles in Armenia. ${ }^{11}$ As a result of the wide-scale repatriation action carried out between March 3 and March 10, 1946, a large number of Poles returned to Poland, but it is not exactly known how many. Not everyone managed to return to their homeland. Those who remained in the USSR after the end of World War II migrated within it, settling in various parts of Russia, including Armenia due to the intensive industrialization of the entire Caucasus. In the face of

9 A. Koseski, Polacy $w$ Armenii, p. 198.

${ }^{10}$ K. Sierocka, Polonia radziecka 1917-1939: z działalności kulturalnej i literackiej [Soviet Polonia 1917-1939: its Cultural and Literary Activities], Warszawa 1968, p. 21; W. TęGOBORSKI, Polacy Związu Radzieckiego. Ich pochodzenie, udziat w Rewolucji Październikowej i budownictwie socjalistycznym. Szkic historyczno-opisowy [Poles of the Soviet Union. Their Origin, Participation in the October Revolution and Socialist Construction. Historical and Descriptive Sketch], Moscow 1929, pp. 102-103; Z. Łukawski, Polonia radziecka $w$ świetle spisu ludności ZSRR w $1926 r$. [Soviet Poles in the Light of the Census of the USSR in 1926], „Zeszyty Naukowe Uniwersytetu Jagiellońskiego. Prace Historyczne" 1986, Vol. 18, pp. 184-186, 188 et seq.; A.F. KLIAJSTER, G.F. CZURsin, Gieografija Zakawkazja. Oczeri po fiziczeskoj geografii i etnografii, Tyflis 1929, p. 5; Nasilenije Zakawkazja. Narodnost - rodnyj jazyk - wozrost-gramotnost. Wsiesojuznaja pierepis nasielenija 1926 god, Kratkije itogi, Tyflis 1928 , p. 8.

${ }^{11}$ AAN, Zwiazek Patriotów Polskich w ZSRR [Union of Polish Patriots in the USSR], Vol. 2020. 
the implementation of the experimental Soviet national policy, which was to lead to the formation of a "Soviet man", meaning a man without a lineage, over time, they officially ceased to identify with their Polish heritage and most often indicated they were of Russian national origin.

After the collapse of the USSR, sealed with a declaration of self-dissolution adopted by the Supreme Soviet of the USSR on December 26, 1991, Armenians began a massive return to Armenia, and some of them with their Polish spouses. Over time, Armenia also became a destination for Poles to go for studies, research, work or volunteer. Some of them have remained there. According to data obtained from the Embassy of the Republic of Poland in Yerevan, 70 people with Polish citizenship and about 220 people declaring Polish origin currently live in Armenia. ${ }^{12}$

124 people declared Polish origin from the information obtained from the Chancellery of the Senate of the Republic of Poland during the 2011 census. $^{13}$ The Armenian Polonia is one of the least numerous of all Polish diasporas. A phenomenon characteristic of the Polish diaspora in Armenia is a fairly large group of ethnic Armenians who admit to their ties to Poland. This mainly applies to people who graduated in Poland and speak Polish fluently, scholarship holders and Polish language course students. It should be added that these figures are only estimates. There is also a large group of people who are aware of their Polish origins but do not attach importance to this or rather identify with the Armenian people.

\section{THE "POLONIA" ASSOCIATION OF POLES IN ARMENIA}

On the tides of reviving the national identity of the inhabitants of the former USSR, associations of those who managed to protect themselves from Soviet national policy began to form. One of them is "Polonia", the Association of Poles in Armenia established in October $1995 .{ }^{14}$ It organizes previously dispersed Poles living in Armenia in joint action for the revival of their national identity. There were about 60 people in the first group of Poles who decided to formalize cooperation. These were people who had already previously known each other and had contacts

12 Information given by the Embassy of the Republic of Poland in Yerevan on February 20, 2019 that the author possesses.

${ }^{13}$ Information given by the Chancellery of the Senate of the Republic of Poland on March 1, 2019 that the author possesses.

${ }_{14}$ According to information obtained in March 2019 from Ms. Ekaterina Isahakyan, the first meeting took place at the headquarters of the Association of Artists in the winter of 1995, and about 30 people attended. Then they met at the Association of National Minorities in Yerevan at Bargamiana street. 
with each other. ${ }^{15}$ Their goal was to associate to provide themselves with an opportunity to deepen their knowledge about the culture, tradition and history of Poland. It was their way of maintaining a bond with their homeland. "Polonia" obtained a legal status on March 12, 1996, when it was officially registered in the Ministry of Justice of the Republic of Armenia.

In 2008, with the help of the Polish Embassy in Yerevan, a branch of "Polonia" was opened in Gyumri. It should be added that "Polonia" not only unites Poles living in Armenia and people of Polish descent; its door is open to all who are interested in Poland, its history, culture and traditions. It conducts activities for the benefit of Poles and people of Polish descent living in Armenia, as well as promotes their cultural heritage and knowledge about Poland in local environments. Ekaterina Isahakyan, a radiologist, was the first President of the "Polonia" Union of Poles in Armenia. The next President of "Polonia" was Ałla Kuźmińska, a professor of philology, who performed this function for 22 years, from March 1996 to March 2018. Currently, Liana Harutyunyan holds the function of the President of "Polonia". She is a private entrepreneur. The headquarters of "Polonia" is located in Yerevan, and as of March 2018, it is located in the very center of the capital at Tumanyan street 28/20, m. 51B.

In addition, there are 2 other Polish diaspora organizations: the socio-charity "Polish House" Cooperation of Poles in Gyumri, which has been operating since 2013 and brings together people of Polish origin and people associated with Poland living in the Province of Shirak in northwestern Armenia; and the "Poland Family" in Yerevan, which has been operating since 2014 and brings together Poles and representatives of other Slavic nationalities, which deals with the promotion of Polish culture and traditions in Armenia. The "Polonia" Union of Poles in Armenia as the only Polish diaspora organization is part of the Coordinating Council for the organization of national minorities at the President of Armenia. It should be added that in Armenia, there are 11 registered national minorities: Yezidi, Russians, Assyrians, Ukrainians, Greeks, Jews, Azeris, Georgians, Belarusians, Germans and Poles. The Polish minority among them is one of the best organized and most active.

According to data from March 2019, The "Polonia" Association of Poles in Armenia gathers about 200 people, which in the context of all people living in $\mathrm{Ar}$ menia who feel they are Poles means that it gathers the entire Polish community. Not everyone who has Polish descent decided to join "Polonia". The contemporary community of people who define themselves as Poles is a community fully assim-

${ }^{15}$ A. KuŹmińska, Polska diaspora we wspótczesnej Armenii, [in:] E. Walewander (red.), Polacy w Armenii [The Polish Diaspora in Modern Armenia, [in:] E. Walewander (ed.), Poles in Armenia], p. 257. 
ilated into the local cultural reality. The disclosure of national separateness and participating in a Polish diaspora organization is dictated above all by the need to emphasize relationships with the homeland of their ancestors and not with Russia, ${ }^{16}$ and as a consequence, they determine their national identity.

The Polish minority in Armenia in most cases (we can say 90\%) does not speak Polish. Some individuals understand Polish, but they can hardly speak Polish. This can be explained by the great distance to Poland, being under the rule of the USSR, and the lack of larger concentrations of Poles on the territory of Armenia. The most important centers in which Poles now live are Yerevan (the nation's capital) and Gyumri (a city in northwestern Armenia, the second largest in size with about 150,000 inhabitants). In addition, individual families also live in Spitak, Vanadzor, Stepanavan, Aszterak, Armavir, Abowianie, Razdanie and Eczmiadzyna. ${ }^{17}$

This process was also due to the lack of a church in which Poles living in Armenia could pray in Polish. Consequently, religious Poles were forced to attend the Armenian Church, in which the liturgy was celebrated in the Armenian language. The Catholic Church for Poles living outside their homeland plays not only a religious, but also an integrating, culture-forming, and educational role. It contributes to shaping and maintaining national awareness, allows keeping a bond with the ancestral homeland, in a word, it is a support center for Polishness. A man who loses the ability to use his native language and is deprived of cultivating religious practices is cut off from his roots.

Therefore, it is not surprising that from the beginning of its existence, "Polonia" has attached great importance to learning the Polish language. Polish lessons are held at the "Polonia" headquarters in Yerevan and in Gyumri in several groups, depending on the level of proficiency. In its beginnings, the classes were conducted by members of "Polonia", but in 2001, the first teachers, Tomasz Musielski and Dominika Izdebska appeared. They were delegated from Poland by the Central Teacher Training Center in Warsaw. Contact with the Polish language is also ensured by the Polish diaspora library organized at the "Polonia" headquarters, whose collections are constantly expanding, both through the purchase of books and thanks to donations by private persons, including guests from Poland visiting "Polonia".

Since 2003, 500 copies of the quarterly „Póki my żyjemy” [“While We Live”] have been published, edited in Polish, Russian and Armenian. The quarterly pub-

16 A. ChOduBSKI, Z dziejów kontaktów polsko-ormiańskich, [in:] E. WALEWANDER (red.), Polacy $w$ Armenii [From the History of Polish-Armenian Contacts, [in:] E. WALEWANDER (ed.), Poles in Armenia], p. 58.

17 A. Kuźmiśska, Polska diaspora we wspótczesnej Armenii, p. 262. 
lishes articles on the history of Poland, the lives and achievements of outstanding Poles, and contains descriptions of Polish traditions and customs, translations of poetry and short prose, information on the current activities of "Polonia", as well as accounts of those who had the opportunity to go to Poland as part of various types of ventures. The quarterly magazine is distinguished by the high level of its content and graphic design. To date, 62 issues of the magazine have been published.

At the initiative of "Polonia", since 2001, the W. Briusowa State University of Foreign Languages and Social Sciences in Yerevan introduced a Polish language course as a second mandatory foreign language for Russian philology. The Polish language is taught as part of the Faculty of Russian Language, Foreign Languages and International Communication. In order to facilitate these classes, the Polish Language Cabinet was established there in 2005, and in 2013 it was transformed into the Adam Mickiewicz Center for Polish Language and Culture. In 2002, a Polish language course was also introduced for students of the Faculty of Russian Philology at Yerevan State University, where the Jan Kochanowski Polish Language Cabinet was created. Thanks to funding from the Polish government, students with the best academic results receive the opportunity to go to Poland for Polish summer courses every year.

Polish diaspora children also go to summer camps to learn about the history of their homeland and improve their language skills. Summer camps are organized annually in Armenia, during which children can learn the Polish language and customs, getting to know their history and tradition through play. Knowledge of the Polish language enables not only interpersonal communication and establishing contacts with members of the Polonia scattered around the world, but also getting to know Polish culture and traditions, understand Polish habits and behaviors, preferences and lifestyles; this allows them to remain faithful to their roots and provides a sense of belonging to one community, regardless of where you live.

The "Polonia's" pride is the children's choir, "Gwiazdeczka", created in 2002, whose performances not only add splendor to the celebration of Polish national and religious holidays, including official banquets organized by the Polish Embassy in Yerevan, but also participates in the annual National Minorities Festival in Armenia, promoting Polish culture and marking the presence of the Polish minority in Armenian society. The choir's repertoire includes not only religious, patriotic and folk songs, but also the most popular Polish songs, while the choir members perform in traditional Polish folk costumes.

The activities of "Polonia" are made possible thanks to the financial assistance provided by the Armenian and the Polish governments. Every year, "Polonia" receives financial support for ongoing operations from the Armenian government due to its status as a national minority, including support for the publication of "While 
We Live" quarterly. In addition, "Polonia" also receives funding for some cultural events, but this type of support is no longer systemic, meaning it is not part of the regular support for national minorities by the Armenian authorities. In addition, there are funds obtained from government subsidies for the implementation of specific projects, whose amount depends on the size of the project and the financial capacity of the Armenian government. Assistance from the Polish government in the first period of "Polonia's" activities was transferred through the Embassy of the Republic of Poland in Moscow because the Embassy of the Republic of Poland in Yerevan was only opened in 2001. Currently, funds granted by the Polish government are transferred through the Polish Community twice a year. These sources are intended to cover expenses related to the maintenance of the association's headquarters and the publication of "While We Live" quarterly.

It should be emphasized that the activities of "Polonia" have a special dimension, since from the very beginning, although they were focused on cultivating Polishness, they carried out this task in the spirit of great respect for Armenian culture. A. Kuźmińska put it very aptly in a commemorative statement on the occasion of the $15^{\text {th }}$ anniversary of the existence of "Polonia" on May 9, 2011, in which she emphasized: "Through our activities and work, we have always tried to show that in the light of all our life circumstances here, we are worthy representatives of the state that welcomed us, the place where we live, and at the same time we deservedly bear the proud name of a Pole". ${ }^{18}$

\section{POLES' CONTRIBUTIONS TO ARMENIA'S SCIENCE AND CULTURE}

In the context of the topic of this research study, it should be emphasized that, throughout history, Poles coming to the lands of historical Armenia have a proud record. This is not surprising, given that many of them were well-educated people, including engineers, architects, doctors and scientists, and such people were always lacking in the Caucasus. It is enough to recall a few examples of those who permanently entered the history of Armenia.

The most important Pole who contributed to Armenia was Józef Chodźko (1800-1881). He was once a member of the underground organization of philomats and filaretts, and later became a lieutenant general of the Russian Empire, a surveyor and topographer. He conducted studies of the Caucasus in the years 1841-

18 Polskie ślady 7: Zwiazek Polaków w Armenii „Polonia” [Polish Traces 7: The "Polonia” Association of Poles in Armenia], http://lehastan.am/?p=539, published on Dec 9, 2014 [accessed: Feb 26, 2019]. 
1865 , which resulted in the first geographical description and triangulation ${ }^{19}$ of the entire area. In the Caucasus, he made about 1,500 hypsometric calculations. He was famous for conquering and exploring Ararat, the holy mountain of the Armenians. ${ }^{20}$ The expedition to Little Ararat (3,925 meters above sea level) and Greater Ararat $(5,165$ meters above sea level) began on July 31,1850 , and he reached the summit of Greater Ararat on August 18, 1850.

Chodźko stayed at the top of the mountain for three days, conducting geodetic and meteorological surveys. Among others, he performed measurements of gravity intensity and was the first to draw attention to the so-called vertical deviations. He was the first Pole (and in general one of the first) to reach the top of Ararat Mountain. Reaching its summit was included in the history of great geographical expeditions. In the same year, Chodźko conquered and explored several other peaks in Armenia, among others Godir (2542 m.a.s.1.). On August 25-30, 1847, he was one of the first to make an expedition to Alaghag, a volcanic cone between Yerevan and Gumry, which he carefully measured and examined. In 1848, he carried out measurements of the Karabakh mountains. ${ }^{21}$

Hieronim Stebnicki (1832-1897) continued the research activity of Józef Chodźko. He was an engineer, surveyor, cartographer, and infantry general of the Russian Empire. He carried out geodetic and cartographic measurements of Armenia, which were used to develop maps, researched mountain peaks, and conducted research in geography and meteorology. In 1868, he finished the convex map sculpture of the Caucasus started by Józef Chodźko. He also studied the impact of the attraction of the Caucasian mountains on the deviation of gravity. ${ }^{22}$

19 Triangulation makes it possible to determine distances between individual points in terrain, allowing accurate maps to be drawn of the surveyed terrain.

${ }^{20}$ Ararat is a volcanic massif, located in the middle of the historical lands of Armenia (currently in Turkey). It includes two extinct volcanoes: Greater Ararat and Little Ararat. Glaciers are found on both mountain tops. Ararat is a symbol of Armenia, a silent witness to its development and decline. According to the Book of Genesis, Noah's Ark settled at this mountain top after the great flood. The higher peak rises over 3000-4400 meters above the surrounding plains, and this is a relative height higher than Mount Everest, https://pl.wikipedia.org/wiki/Ararat [accessed: Feb 26, 2019].

${ }^{21}$ Cf. E. Berezowski, Józef Chodźko - geodeta i geograf XIX wieku (1800-1881) [Józef Chodźko - $19^{\text {th }}$ Century Surveyor and Geographer (1800-1881)], ,Przegląd Geodezyjny” 42(1970), no. 10, pp. 371-372; J. ReYchman, Podróżnicy polscy na Bliskim Wschodzie w XX wieku [Polish Travelers in the Middle East in the $20^{\text {th }}$ Century], Warszawa 1972, p. 231 et seq.; A. FurIER, Józef Chodźko 1880-1881. Polski badacz Kaukazu [Józef Chodźko 1880-1881. Polish Researcher of the Caucasus], Warszawa 2001.

${ }^{22}$ Cf. M. ZIELIŃSKI, Mały stownik pionierów polskich kolonialnych i morskich [A Small Dictionary of Polish Colonial and Maritime Pioneers], Warszawa 1933, p. 503; A. CHOdUBSKI, Hieronim Stebnicki i jego działalność geodezyjna i kartograficzna na Kaukazie, [in:] A. CHODUBSKI (red.), Swo- 
Ludwik Młokosiewicz (1831-1909) was a distinguished Pole who studied the flora and fauna of Armenia and the entire Caucasus in general. He was a zoologist and botanist, traveler and hunter. As a volunteer, he signed up for military service in the Caucasus, after which he remained in Georgia for the rest of his life, working as a ranger in the southeastern part of the town of Lagodechi. Młokosiewicz discovered about 60 plants and animals unknown to science, some of which were named after him, among others the Caucasian black grouse (Tetrao Mlokosiewiczi), the Caucasian salamander (Salamandra Caucasica), the Caucasian pine (Pinus Eldarica), and the Yellow peony (Paeonia Mlokosiewiczi). ${ }^{23}$

By discovering and exploring the Caucasus' natural environment, he delivered many specimens of the plant and animal world to various museums and institutions. To this day in Poland, the Museum and Institute of Zoology of the Polish Academy of Sciences has its ornithological collection, while the Department of Systematic and Experimental Zoology of the Polish Academy of Sciences has entomological collections. He was the author of over 50 scientific notes and articles in the field of farming and agriculture, mainly concerning the natural environment of the Caucasus. Młokosiewicz’s great passion was mountain climbing. In 1889, he organized an expedition to Mount Ararat, in which his daughter Julia Młokosiewicz took part. She was the first woman to climb Ararat. Born with her father's passion for research, she continued his study of the flora and fauna of Armenia, discovering many previously unknown species, among which the most famous is the Caucasian primrose (Primula Juliae). ${ }^{24}$

Bolesław Hryniewiecki (1857-1919) also dealt with the study of Caucasian nature. He discovered the peculiarities of Mount Ararat, the Ayrejic cinquefoil, which he dug up from under the snow at an altitude of about 4,500 $\mathrm{m}$ a.s.1. He also said that Ararat has plants that are found nowhere else in the world..$^{25}$

istości cywilizacyjne, kwestie narodowościowe i polonijne [Hieronim Stebnicki and His Geodetic and Cartographic Activities in the Caucasus, [in:] A. Chodubski (ed.), Civilization Specificities, Nationality and Polish Diaspora Issues], Torun 1999, pp. 125-137.

${ }^{23}$ Cf. B. Hryniewiecki, Ludwik Młokosiewicz. Miłośnik i badacz przyrody Kaukazu (1831-1909) [Ludwik Młokosiewicz. Lover and Explorer of Wildlife in the Caucasus (1831-1909)], „Wszechświat" 1950, no. 5, pp. 136-139; A. CHODuBsKi, Ludwik Młokosiewicz (1831-1909) - pionier badań flory i fauny Kaukazu [Ludwik Młokosiewicz (1831-1909). Pioneer of Research on the Flora and Fauna of the Caucasus], „Kwartalnik Historia Nauki i Techniki” 1982, Vol. 27, no. 2, pp. 421-428.

${ }^{24}$ Cf. B. HryniewIeCKI, Ludwik Młokosiewicz. Miłośnik i badacz przyrody Kaukazu, pp. 136139; J. Reychman, Podróżnicy polscy na Bliskim Wschodzie w XIX wieku [Polish Travelers in the Middle East in the 19 ${ }^{\text {th }}$ Century], Warszawa 1972, p. 244.

${ }^{25}$ Cf. M. ZIELIŃSKI, Maty słownik pionierów polskich kolonialnych i morskich [A Small Dictionary of Polish Colonial and Maritime Pioneers], Warszawa 1933, pp. 154-156; W. KUBACKI, Malwy na Kaukazie [Malva in the Caucasus], Warszawa 1969, p. 181. 
The most recognized Pole is Edmund Leonowicz (1902-1986), architect, founder and guardian of the only dendrological park in Armenia. "Sośniaki" is located near the village of Giulagarak near Stepanawanu in the province of Lorri in the north-eastern part of Armenia. In 1933, commissioned by the forest management, he began to arrange a dendrological park on the northern slopes of the Batum Mountains, and worked continuously for over half a century, earning himself the title "father of forests". The park is located at an altitude of $1550 \mathrm{~m}$ above sea level and currently covers an area of 35 hectares, of which about 18 hectares is a forest covered by Siberian pine (Pinus sibirica), while 15 hectares is a collection of variously introduced plants. During the times of the USSR, about 2,500 species of plants grew in the park, but currently, there are only about 500 . The dendrological park is a state research institution and at the same time a recreational center. Edmund Leonowicz was buried among the trees in the dendrological park. His son Vitaly continued his work for many years. ${ }^{26}$

Art historian Józef Strzygowski (1862-1941) is also worth mentioning. He participated in archaeological research and the reconstruction of the $7^{\text {th }}$ century ruins of the Cathedral of St. Gregory the Illuminator in Zvartnoc, about $15 \mathrm{~km}$ west of Yerevan. The ruins of the cathedral, recognized as the peak achievement of $\mathrm{Ar}$ menian architecture, were included on the UNESCO World Heritage List in 2000.

Despite the many outstanding people who have contributed to the Armenian nation, we regret to say that they are absent in the general consciousness. They were also not in any way commemorated in the public space in the form of monuments or even commemorative plaques that would remind Armenians of Poles who distinguished themselves for Armenia. It seems that the Polish authorities do not have any ideas on how to commemorate Poles for their distinguished service to Armenia. Since the opening of the Polish embassy in Yerevan, the Polish authorities have only "managed" to have one of the side streets in the city center be named after Rafał Lemkin (1900-1959), a Polish lawyer of Jewish origin, creator of the legal concept of the crime of genocide and the draft of the Convention on the prevention and punishment for the crime of genocide adopted by the General Assembly of the United Nations on December 9, 1948, ${ }^{27}$ called the "Lemkin Convention".

Due to the fact that he wrote his most important book, The Axis Rule in Occupied Europe, in which he defined the concept of genocide after emigrating to the United States and published it there, hardly anyone associates it with Poland. In this

${ }^{26}$ Dendropark Stepanawan, https://pl.wikipedia.org/wiki/Dendropark_Stepanawan, [accessed: Jan 26, 2019].

${ }^{27}$ Convention on the Prevention and Punishment of the Crime of Genocide adopted by the General Assembly of the United Nations on December 9, 1948, "Journal of Laws" 1952, no. 2, item 9. 
respect, it should be emphasized that over the 18 years of the Polish Embassy in Yerevan's activity, this is not much. Other traces of Polish presence in Armenia include the bust of Rafał Lemkin located on the campus of Yerevan State University, unveiled at the initiative of the university authorities, and a commemorative plaque placed on the grave of Edmund Leonowicz located in the "Sośniaki" dendrological park near the village of Giulagarak at the initiative of the "Polonia" Association of Poles in Armenia funded by the Senate of the Republic of Poland, with information about the achievements of its founder.

In the context of maintaining and reviving national awareness among Poles scattered throughout the world, it is necessary for state authorities, the Catholic Church and social organizations to undertake projects on various levels of life that support the strengthening and cultural development of Polish diaspora organizations. One such venture may be to bring back the memory of the achievements of Great Poles regardless of where they live. This, however, requires a thoughtful, coherent and consistently implemented concept of historical policy, emphasizing the merits of Poles in the international arena. Such activities can become a source of pride in belonging to the Polish Nation, providing new inspirations that can contribute to building Poland's strong position and respect for Poles and the Polish diaspora throughout the world.

\section{BIBLIOGRAPHY}

AAN, Związek Patriotów Polskich w ZSRR [Union of Polish Patriots in the USSR], Vol. 2020.

Ararat, https://pl.wikipedia.org/wiki/Ararat [accessed: Feb 26, 2019].

Berezowski E., Józef Chodźko - geodeta i geograf XIX w. (1800-1881) [Józef Chodźko $-19^{\text {th }}$ Century Surveyor and Geographer (1800-1881)], „Przegląd Geodezyjny” 42(1970), no. 10 .

Chodubski A., Hieronim Stebnicki i jego działalność geodezyjna i kartograficzna na Kaukazie, [in:] A. Chodubski (red.), Swoistości cywilizacyjne, kwestie narodowościowe i polonijne [Hieronim Stebnicki and his Geodetic and Cartographic Activities in the Caucasus, [in:] A. Chodubski (ed.), Civilization Specificities, Nationality and Polonia Issues], Toruń: Wydawnictwo Adam Marszałek 1999.

Chodubski A., Ludwik Młokosiewicz (1831-1909) - pionier badań flory i fauny Kaukazu [Ludwik Młokosiewicz (1831-1909). Research Pioneer on the Flora and Fauna of the Caucasus], „Kwartalnik Historii Nauki i Techniki” 1982, Vol. 27, no. 2.

Chodubski A., Z dziejów kontaktów polsko-ormiańskich, [in:] E. WALEWANDER (red.), Polacy w Armenii [The History of Polish-Armenian Contacts, [in:] E. WALEWANDER (ed.), Poles in Armenia], Lublin: RW KUL 2000. 
Dendropark Stepanawan, https://pl.wikipedia.org/wiki/Dendropark_Stepanawan [accessed: Feb 26, 2019].

Furier A., Józef Chodźko 1880-1881. Polski badacz Kaukazu [Józef Chodźko 1880-1881. Polish Researcher of the Caucasus], Warszawa: Trio 2001.

HrYNIEWIECKI B., Ludwik Młokosiewicz. Miłośnik i badacz przyrody Kaukazu (18311909) [Ludwik Młokosiewicz. Lover and Explorer of Nature of the Caucasus (18311909)], „Wszechświat” 1950, no. 5.

Information provided by the Polish Embassy in Yerevan on February 20, 2019, in the possession of the author.

Information provided by Ekaterina Isahakyan on March 16, 2019, in the possession of the author.

Information provided by the Chancellery of the Senate of the Republic of Poland on March 1, 2019, in the possession of the author.

KLiaJster A.F., Czursin G.F., Gieografija Zakawkazja. Oczeri po fiziczeskoj geografii i etnografii, Tyflis 1929, p. 5; Nasilenije Zakawkazja. Narodnost - rodnyj jazyk - wozrost - gramotnost. Wsiesojuznaja pierepis nasielenija 1926 god, Kratkije itogi, Tyflis 1928.

Convention on the Prevention and Punishment of the Crime of Genocide adopted by the General Assembly of the United Nations on December 9, 1948, "Journal of Law" 1952, no. 2 , item 9.

KoSESKI A., Polacy w Armenii: problematyka kwerendy i główne kierunki badań [Poles in Armenia: Query Issues and Main Research Trends], „Dzieje Najnowsze” 2000, no. 1.

Koseski A., Przemówienie inaugurujące sympozjum naukowe „Polacy w Armenii na tle dziejów ormiańskich", [in:] E. Walewander (red.), Polacy w Armenii [Inaugural Speech of the Academic Symposium „Poles in Armenia in the Background of Armenian History", [in:] E. WALEWANDER (ed.), Poles in Armenia], Lublin: RW KUL 2000.

KuBACKi W., Malwy na Kaukazie [Mallows in the Caucasus], Warszawa: Czytelnik 1969.

KuŹMiŃsKa A., Polska diaspora we współczesnej Armenii, [in:] E. Walewander (red.), Polacy w Armenii [The Polish Diaspora in Contemporary Armenia, [in:] E. WALEWANDER (ed.), Poles in Armenia], Lublin: RW KUL 2000.

ŁUKAWSKi Z., Polonia radziecka w świetle spisu ludności ZSRR w 1926 r. [Russian Poles in the USSR Census of 1926], „Zeszyty Naukowe Uniwersytetu Jagiellońskiego. Prace Historyczne" 1986, folder 18.

NAJDus W., Uchodźcy polscy w Rosji w latach 1917-1919 [Polish Exiles in Russia in 19171919], ,Kwartalnik Historyczny” 1957, no. 6.

Patek A., Polacy w Rosji i w ZSRR, [in:] B. Szydeowska-Ceglowa (red.), Polonia w Europie [Poles in Russia and the Soviet Union, [in:] B. Szydlowska-Ceglowa (ed.), Polonia in Europe], Poznań: PAN 1992.

Pierwaja wsieobszczaja pierepis nasielenija Rossijskoj Imperii 1897 goda, Vol. 71, Petersburg 1905.

PIWNICKI G., Losy Polaków - wojskowych, służących w armii carskiej na terenie Armenii w XIX i na początku XX w., [in:] E. Walewander (red.), Polacy w Armenii [The Fate of Military Poles Serving in the Tsar's Army in Armenia in the $19^{\text {th }}$ and Beginning 
of the $20^{\text {th }}$ Century, [in:] E. Walewander (ed.), Poles in Armenia], Lublin: RW KUL 2000.

Polskie ślady 7: Związek Polaków w Armenii „Polonia” [The „Polonia” Polish Society in Armenia], http://lehastan.am/?p=539, published Dec 9, 2014 [accessed: Feb 26 2019]. Razpredielenije nasielenija Zakawkazskogo Kraja po wierospowiedanijam i rodnomu jazyku po dannym pierepisii 1897 g., [in:] Kawkazskij Kalendar na 1907 god, Tyflis 1906. Reychman J., Podróżnicy polscy na Bliskim Wschodzie w XX wieku [Polish Travelers in the Middle East in the 20 $0^{\text {th }}$ Century], Warszawa: Wiedza Powszechna 1972.

SiERocka K., Polonia radziecka 1917-1939: z działalności kulturalnej i literackiej [Russia’s Polonia 1917-1939: Their Cultural and Literary Activities], Warszawa: PIW 1968.

TęGoborski W., Polacy Związku Radzieckiego. Ich pochodzenie, udział w Rewolucji Październikowej i budownictwie socjalistycznym. Szkic historyczno-opisowy [Poles in the Soviet Union. Their Origins, Participation in the October Revolution and Special Constructions. A Historical Outline], Moscow 1929.

Zakrzewska-Dubasowa M. (ed.), Polacy w kulturze i życiu społecznym Zakaukazia do 1918 r. [Poles in the Culture and Social Life of Caucasia until 1918], Lublin: UMCS 1990.

ZIELIŃSKI M., Mały słownik pionierów polskich kolonialnych i morskich [Small Dictionary of Polish Colonial and Maritime Pioneers], Warszawa: Instytut Wydawniczy Ligi Morskiej 1933.

\section{THE POLISH MINORITY IN ARMENIA}

\section{Sum mary}

The geopolitical location determined the fate of the Polish nation. The rivalry between East and West was the basic reason for the migration of the Polish population. As a consequence, a huge number of Poles, mainly intelligentsia, found themselves outside Poland. Their descendants today live on all continents, in almost all countries of the world. One of the settlement areas of the Polish population was the Transcaucasus, including the historical lands of Armenia. Unfortunately, the fate of Polish settlement and Poles living in Armenia is an almost unknown issue. The purpose of the study is to recover from oblivion the fate of the Polish minority in Armenia.

Key words: Poles during the partitions; Polish settlement in Armenia; legal status of the Polish minority in Armenia; activity of Poles living in Armenia; Poles distinguished for the science and culture of Armenia 


\section{MNIEJSZOŚĆ POLSKA W ARMENII}

\section{Streszczenie}

Położenie geopolityczne zdeterminowało losy narodu polskiego. Rywalizacja między Wschodem i Zachodem była podstawową przyczyną migracji ludności polskiej. W konsekwencji poza granicami Polski znalazła się ogromna liczba Polaków, głównie inteligencji. Ich potomkowie żyją dzisiaj na wszystkich kontynentach, niemal we wszystkich państwach świata. Jednym z obszarów osiedlania się ludności polskiej było Zakaukazie, w tym również ziemie historyczne Armenii. Niestety losy osadnictwa polskiego i Polaków mieszkających w Armenii to zagadnienie prawie nieznane. Celem opracowania jest wydobycie z zapomnienia losów mniejszości polskiej w Armenii.

Słowa kluczowe: Polacy w okresie zaborów; osadnictwo polskie w Armenii; status prawny mniejszości polskiej w Armenii; aktywność Polaków mieszkających w Armenii; Polacy zasłużeni dla nauki i kultury Armenii 